\title{
PERSISTENSI INFLASI DI JAKARTA DAN IMPLIKASINYA TERHADAP KEBIJAKAN PENGENDALIAN INFLASI DAERAH
}

\author{
Trinil Arimurti, Budi Trisnanto ${ }^{1}$
}

\begin{abstract}
The main objective of this study is to measure the persistence of inflation level in Jakarta. In addition, this study intends to find out the source of inflation persistence and its implication to regional inflation control. The analysis of the regional inflation behavior developed in this paper is explored to commodities level. The empirical result indicates that the level of inflation persistence in Jakarta is relatively high, stemmed from high level of inflation persistance for most of commodities that construct inflation. Using the estimation results of the hybrid NKPC model, it shows that high inflation persistence in Jakarta mainly caused by inflation expectation, which is a combination of forward and backward looking. In this regards, it requires efforts gradually transform the behavior of inflation expectation to be more forward looking.
\end{abstract}

Keywords: inflation peristence, expectation, NKPC.

JEL Classification:E31, R10

1 Penulis adalah peneliti ekonomi muda senior dan peneliti ekonomi madya di Biro Riset Ekonomi, Bank Indonesia. Penulis mengucapkan terima kasih kepada Yoni Depari, Sugiharso Safuan serta rekan-rekan di Biro Riset Ekonomi dan Biro Kebijakan Moneter, atas masukan, saran dan diskusi yang sangat konstruktif. e-mail: trinil@bi.go.id, b_trisnanto@bi.go.id 


\section{PENDAHULUAN}

Sesuai Undang-undang (UU) No. 13 tahun 1968 tentang Bank Indonesia sebagaimana telah diubah terakhir dengan UU No. 4 tahun 2003, tugas Bank Indonesia adalah mencapai dan menjaga kestabilan nilai Rupiah, yang salah satunya adalah dalam bentuk kestabilan nilai Rupiah terhadap barang dan jasa atau kestabilan inflasi. Dengan demikian, kebijakan moneter diarahkan untuk mencapai dan menjaga inflasi pada tingkat yang rendah dan stabil. Dalam kaitan tersebut, respon kebijakan moneter tidak hanya ditentukan oleh tingkat inflasi yang ingin dicapai tetapi ditentukan pula oleh perilaku inflasi itu sendiri. Hal tersebut akan menentukan besaran dan waktu (timing) respon kebijakan moneter yang perlu diterapkan dalam rangka mencapai inflasi yang ingin dicapai tersebut. Dari sisi tingkat inflasi yang ingin dicapai, kebijakan moneter diarahkan untuk mencapai sasaran inflasi yang ditetapkan menurun secara gradual menuju tingkat yang mendukung pertumbuhan ekonomi yang berkesinambungan. Sesuai UU dimaksud, sasaran inflasi ditetapkan oleh Pemerintah setelah berkoordinasi dengan Bank Indonesia yang dimaksudkan untuk meningkatkan kredibilitas kebijakan moneter. Sementara itu, asesmen mengenai perilaku inflasi yang diperlukan antara lain terkait dengan persistensi inflasi atau kecepatan tingkat inflasi untuk kembali ketingkat ekuilibriumnya setelah timbulnya suatu shock.

Beberapa penelitian telah dilakukan untuk melihat persistensi inflasi di Indonesia. Hasil studi Yanuarti (2007) dan Alamsyah (2008) misalnya menyimpulkan bahwa derajat persistensi inflasi di Indonesia secara umum sangat tinggi namun cenderung menurun pada periode setelah krisis. Sementara itu, Harmanta (2009) menyatakan bahwa persistensi inflasi yang bersifat backward looking pada era ITF mengalami penurunan, sementara yang bersifat forward looking mengalami peningkatan. Namun demikian, kajian tersebut perlu didukung oleh kajian yang bersifat regional, dalam arti melihat lebih dalam persistensi inflasi di tingkat regional. Hal ini juga juga dilatarbelakangi oleh pemahaman bahwa inflasi nasional dibentuk dari inflasi daerah. Secara lebih spesifik, kajian persistensi inflasi di daerah dengan mempertimbangkan bahwa masing-masing daerah memiliki karakteristik inflasi yang berimplikasi pada kebijakan pengendalian inflasi yang spesifik meski secara umum tekanan inflasi di daerah banyak terkait dengan kejutan di sisi pasokan.

Implementasi Inflation Targeting Framework (ITF) pada tahun 2005 menjadi tonggak sejarah perubahan kerangka kebijakan moneter yang dilakukan pasca krisis ekonomi di Indonesia. Pada prinsipnya kerangka kebijakan moneter tersebut adalah dalam rangka mengadopsi kerangka kebijakan yang lebih kredibel, yang mengacu pada penggunaan suku bunga sebagai operational target dan kebijakan yang bersifat antisipatif. ITF diharapkan dapat mengubah backward looking expectation, yang menjadi sumber masih tingginya inflasi, menjadi forward 
looking expectation. Dengan demikian, diharapkan ITF dapat mendorong penurunan persistensi inflasi.

Selanjutnya, kajian persistensi inflasi perlu didukung dengan analisis mengenai penyebab persistensi inflasi. Sebagaimana dimaklumi dalam komponen inflasi IHK terdapat komponen yang harganya dipengaruhi oleh kebijakan Pemerintah di bidang harga dan pendapatan (administered prices). Harga pada kelompok komoditi ini cenderung flat dan berubah bila ada kebijakan Pemerintah. Selain itu, terdapat komponen yang harganya banyak terpengaruh supply shocks atau yang bersifat musiman. Untuk itu, diperlukan asesmen untuk melihat secara lebih rinci faktor-faktor yang bersifat fundamental. Hal ini dimaksudkan agar respon kebijakan moneter dapat dilakukan secara lebih tepat mengingat kebijakan moneter ditujukan untuk demand management. Dengan kata lain, respon kebijakan moneter tidak perlu dilakukan secara berlebih bila sumber tekanan inflasi berasal dari faktor yang bersifat non-fundamental.

Kajian mengenai fenomena persistensi menjadi sangat penting untuk dilakukan dalam rangka mendukung perumusan kebijakan moneter yang efektif. Hal ini dikarenakan agar efektifitas kebijakan moneter dapat mendukung pertumbuhan ekonomi yang berkesinambungan dalam rangka meningkatkan kesejahteraan masyarakat. Inflasi yang tinggi akan memberikan dampak negatif terhadap perekonomian. Daya beli masyarakat menurun dan pelaku dunia usaha akan diliputi ketidakpastian yang tinggi. Implikasi dari persistensi inflasi tersebut juga akan dirasakan di tingkat daerah sehingga perlu mendapat perhatian pemerintah daerah setempat untuk dapat berperan aktif dalam mengendalikan inflasi.

Kajian tersebut pada akhirnya diperlukan untuk merumuskan strategi pengendalian inflasi. Sumber tekanan inflasi yang menyebabkan persistensi inflasi perlu dianalisa secara lebih tajam sehingga dapat dibedakan sumber tekanan inflasi yang bersifat fundamental dan yang hanya bersifat sementara atau temporer. Kebijakan moneter tidak dapat digunakan sepenuhnya untuk merespon tekanan inflasi dari kejutan di sisi pasokan. Diperlukan kebijakan sektoral dan regional untuk mengurangi tekanan inflasi dari faktor-faktor non-fundamental.

Beberapa studi persistensi inflasi yang telah dilakukan sebelumnya di Indonesia lebih difokuskan pada skala nasional. Inflasi nasional merupakan rata-rata tertimbang dari inflasi daerah di Indonesia, maka dirasa perlu untuk mempelajari perilaku inflasi di tingkat daerah, termasuk mengukur dan mencari penyebabnya, serta mengetahui implikasinya terhadap pengendalian inflasi daerah dengan fokus kota Jakarta.

Pemilihan wilayah Jakarta didasarkan pada dominasinya terhadap bobot inflasi nasional dibandingkan dengan daerah lainnya di Indonesia. Meskipun terdapat kecenderungan yang menurun, bobot inflasi kota Jakarta masih merupakan yang terbesar diantara 66 kota yang diukur melalui Survei Biaya Hidup (SBH). Data tahun 2007 menunjukkan bahwa bobot Jakarta 
mencapai 22,49\% dari bobot nasional (Grafik 1), menurun dari 27,66\% berdasarkan SBH tahun 2002. Alasan lainnya adalah pergerakan volume distribusi barang kebutuhan pokok yang sangat tinggi di Jakarta. Selanjutnya perilaku inflasi Jakarta tersebut akan dibandingkan dengan Nasional dan panel 10 daerah dengan kontribusi inflasi tertinggi di Indonesia.

Untuk menjawab tujuan penelitian, cakupan rentang waktu studi meliputi periode Januari 2000 s.d Mei 2008 (Jakarta) dan Januari 2000 s.d Desember 2009 (nasional). Hal ini terkait dengan ketersediaan data dari BPS hingga di level komoditinya.

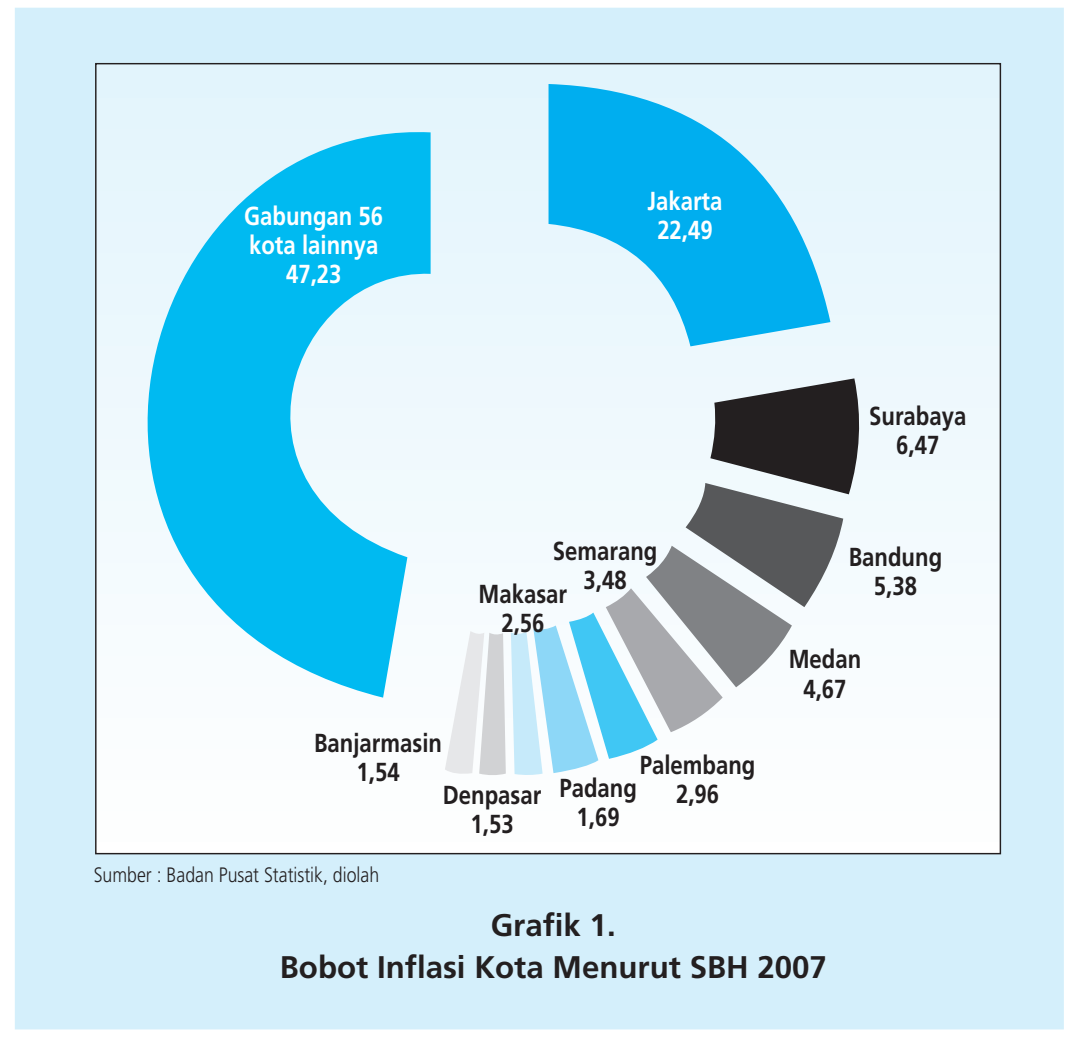

\section{TEORI}

Persistensi inflasi menurut Marques (2005) diartikan sebagai kecepatan tingkat inflasi untuk kembali ke tingkat ekuilibriumnya setelah timbulnya suatu shock. Tingkat kecepatan yang tinggi menunjukkan bahwa tingkat persistensi inflasi rendah dan sebaliknya tingkat persistensi inflasi yang tinggi ditunjukkan oleh lamanya tingkat inflasi kembali ke level ekuilibriumnya. Definisi yang hampir serupa juga dikemukakan Willis (2003) yang mengartikan persistensi inflasi sebagai waktu yang dibutuhkan oleh inflasi untuk kembali ke baseline setelah adanya shock. Sementara itu, alternatif definisi yang lebih beragam dikemukakan oleh Batini 
(2002) yang membahas tiga tipe persistensi inflasi, yaitu(i) "positive serial correlation in inflation"; (ii) "lags between systematic monetary policy actions and their (peak) effect on inflation"; (iii) "lagged responses of inflation to non-systematic policy actions".

Studi mengenai persistensi inflasi penting untuk meningkatkan kemampuan peramalan inflasi, memperoleh kejelasan efek dinamis dari exogenous price shocks, memberikan informasi/ petunjuk dan memperbaiki kebijakan moneter, dan untuk menilai apakah rezim kebijakan moneter yang berbeda akan menghasilkan persistensi yang berbeda, Stock (2004).

\subsection{Pengukuran Persistensi Inflasi}

Untuk mengukur tingkat persistensi inflasi, terdapat dua pendekatan yang dapat digunakan, yaitu pendekatan univariat dan multivariat model. Pendekatan univariat lebih menekankan hanya pada aspek data time series, sedangkan pendekatan multivariat mencakup juga tambahan informasi seperti output riil dan tingkat suku bunga bank sentral (Dossche and Everaert, 2005). Dari beberapa studi yang telah dilakukan, pendekatan univariat dengan menggunakan model autoregressive (AR) time series merupakan yang pendekatan yang paling lazim dalam riset empiris.

Beberapa metode pengukuran skalar (univariat) yang dapat digunakan untuk menghitung persistensi inflasi, antara lain (i) the sum of the autoregressive(AR) coefficients; (iii) the largest autoregressive root; (iv) the half-life (Marques, 2005). Dengan model AR, tingkat persistensi inflasi diukur dari hasil penjumlahan koefisien lag variable dependennya. Sementara itu, metode LAR (thelargest autoregressive root) secara garis besar dijelaskan oleh Levin dan Piger (2004). Dalam metode ini, persistensi inflasi diperoleh dengan mencari akar terbesar dari persamaan $\lambda^{K}-\sum_{j=1}^{K} \alpha_{j} \lambda^{K-j}=0$. Sedangkan metode thehalf-life diadopsi terutama untuk mengevaluasi persistensi deviasi dari purchasing power parity equilibrium (Marques 2004). Sebagaimana diuraikan oleh Andrews dan Chen (1994), formula thehalf-life adalah $\gamma=1-\frac{n}{T^{\prime}}$ dimana $\mathrm{n}$ adalah jumlah berapa kali inflasi berada di atas nilai 0,5 ketika terjadi gangguan sebesar 1 unit dan T adalah jumlah periode observasi. Meskipun terdapat beberapa berbagai konsep pengukuran tingkat persistensi inflasi yang berbeda, hasil estimasi yang diperoleh ternyata secara umum tidak jauh berbeda (Clark, 2003).

Fokus penelitian pada proses inflasi memungkinkan penggunaan model univariat dalam paper ini. Namun demikian, model univariat tidak terlepas dari beberapa keterbatasan, salah satunya adalah bahwa model ini tidak dapat mengidentifikasi sumber penyebab dari the observed 
persistence inflasi sehingga terdapat kemungkinan pemicu potensial proses inflasi menjadi terabaikan.

Marques (2004) menyatakan bahwa model AR merupakan pengukur persistensi inflasi yang cukup baik, serta berkaitan langsung dengan koefisien mean reversion sebagai alternatif pengukuran tingkat persistensi inflasi. Formula AR dengan order $\mathrm{p}$ dapat dijabarkan sebagai berikut:

$$
\pi_{t}=\mu+\sum_{j=1}^{K} \alpha_{j} \pi_{t-j}+\varepsilon_{t}
$$

$\pi_{t} \quad$ : tingkat inflasi bulanan pada waktu $\mathrm{t}$

$\mu \quad$ : konstanta dari hasil proses estimasi, sebagai kontrol terhadap rata-rata inflasi

$\sum_{j=1}^{K} \alpha_{j}:$ jumlah koefisien AR

$\varepsilon_{t} \quad$ : random error term atau residual dari regresi persamaan di atas

Dari hasil estimasi persamaan tersebut, tingkat persistensi inflasi dihitung dengan menjumlahkan koefisien $A R,\left(\rho \equiv \sum_{j=1}^{K} \alpha_{j}\right)$. Cara penjumlahan koefisien tersebut merupakan cara pengukuran skalar persistensi terbaik menurut Andrews dan Chen (1994). Persistensi inflasi dikatakan tinggi apabila tingkat inflasi saat ini sangat dipengaruhi oleh nilai lag-nya, sehingga koefisiennya mendekati 1. Dalam hal ini, inflasi dikatakan mendekati unit root process.

Untuk memperoleh hasil estimasi, disetiap series inflasi perlu ditentukan jumlah lag variable dependen yang sesuai. Dalam penentuannya, dapat digunakan Akaike Information Criterion (AIC) ataupun Schwarz' Bayesian Information Criterion (SBIC). Sebagaimana dikemukakan Levin dan Piger (2004), dalam mengukur persistensi dengan AR model, persamaan ekuivalen berikut perlu dipertimbangkan pula:

$$
\pi_{t}=\mu+\rho \pi_{t-1}+\sum_{j=1}^{K-1} \phi_{j} \Delta \pi_{t-j}+\varepsilon_{t}
$$

Dimana parameter dinamik $\phi_{j}$ merupakan transformasi sederhana dari koefisien AR dari persamaan (1). 
Secara lebih spesifik, konsep persistensi sangat berhubungan dengan Impulse Response Function (IRF) dari proses AR (p). Marques (2004) menguraikan kelemahan dan keunggulan masing-masing metode pengukuran persistensi. Konsep Cumulative Impulse Response Function (CIRF) yang diformulakan sebagai $C I R F=\frac{1}{1-\rho}$ menggambarkan adanya hubungan monotonic antara CIRF dengan koefisien AR $(\rho)$, sehingga perhitungannya sangat tergantung kepada koefisien AR. Kelemahan lain dari CIRF dan $\rho$ dalam mengukur persistensi inflasi adalah apabila terdapat 2 series data, kedua metode tersebut tidak bisa membedakan antara series yang awalnya meningkat sangat tinggi yang kemudian diikuti dengan penurunan secara perlahan dengan series yang awalnya peningkatannya rendah dan kemudian diikuti dengan penurunan yang tinggi di IRF-nya. Terlepas dari adanya keterbatasan yang menjadi kelemahan dari metode univariat, metode skalar pengukuran persistensi ini harus dilihat sebagai metode untuk mengestimasi kecepatan rata-rata inflasi untuk kembali ke nilai equilibriumnya setelah timbulnya suatu shock. Metode pengukuran skalar ini dinilai semakin handal apabila kecepatan konvergensi series inflasi semakin seragam.

Beberapa kritik terhadap metode the half life dalam perhitungan tingkat persistensi inflasi juga telah dilontarkan dalam penelitian sebelumnya. Apabila IRF bersifat oscillating, metode ini dapat menghasilkan persistensi proses inflasi yang terlalu rendah. Di samping itu, bila proses inflasi bersifat sangat persisten, output dari the half-life sangat besar sehingga sulit untuk bisa membedakan perubahan persistensi seiring berjalannya waktu. Namun seringkali metode ini lebih disukai karena lebih mudah dipahami karena pengukurannya dalam unit waktu.Karena keterbatasan tersebut, beberapa penulis melakukan perhitungan the half life secara langsung dari IRF.Sementara itu, kritik terhadap metode the largest autoregressive rootpernah diungkapkan Marques (2004). Pengukuran persistensi dengan metode ini dinilai tidak cukup baik karena fungsinya juga tergantung pada root lainnya, bukan hanya pada root terbesarnya. Namun, keunggulan dari metode ini adalah kemudahannya dalam menghitung asymptotically valid convidence intervals untuk hasil estimasinya.

Hasil pengukuran derajat persistensi inflasi dengan model AR yang diestimasi dengan menggunakan OLS dapat dibandingkan dengan hasil estimasi bootstrap. Hal ini juga berguna untuk mengantispasi kemungkinan pengukuran yang kurang valid apabila derajat persistensi mendekati angka 1, sehingga robustness check penting untuk dilakukan. Prosedur ini telah digunakan dibeberapa penelitian sebelumnya, antara lain O'Reilly dan Whelan (2004) dan Alamsyah (2008).

Melengkapi pengamatan terhadap perubahan perilaku inflasi, metode rolling regression dapat digunakan untuk melihat apakah proses inflasi mengalami perubahan seiring dengan 
waktu, dengan cara melihat evolusi dari koefisien AR. Metode ini telah dilakukan pula dibeberapa penelitian terdahulu antara lain Pivetta \& Reis (2006), Debelle and Wilkinson (2002), O'Reilly dan Whelan (2004) dan Alamsyah (2008). Secara umum disimpulkan bahwa hasil estimasi derajat persistensi inflasi dengan metode tersebut menunjukkan telah terjadi perubahan proses inflasi di negara-negara yang menjadi obyek sampel. Namun demikian, metode ini juga memiliki kelemahan karena tidak terlalu akurat menunjukkan saat terjadinya perubahan tingkat persistensi inflasi, sehingga pengaruh faktor-faktor seperti perubahan kebijakan moneter tidak dapat ditangkap secara jelas.

Dalam melakukan analisis terhadap derajat persistensi inflasi, perlu juga dipertimbangkan keberadaan structural breaks. Beberapa literatur menyebutkan bahwa estimasi tingkat persistensi inflasi akan berlebihan (exaggerated) apabila keberadaan structural break nilai rata-rata inflasi tidak diperhitungkan. Beberapa teknik seperti Andrew and Quandt test ataupun Chow testdapat dilakukan untuk melakukan tes terhadap keberadaan structural break.

Untuk mengukur berapa lama waktu yang diperlukan inflasi dalam menyerap 50\% shock yang terjadi sebelum kembali ke nilai rata-ratanya, dapat digunakan formula (Gujarati, 2003) dengan formula sederhana $h=\frac{\rho}{1-\rho}$. Adapun $h$ merupakan waktu yang diperlukan inflasi dalam menyerap 50\% shock yang terjadi sebelum kembali ke nilai rata-ratanya dan $\rho$ adalah hasil estimasi derajat persistensi inflasi.

Beberapa studi terkait dengan persistensi inflasi telah dilakukan di Indonesia, antara lain oleh Alamsyah (2008), Yanuarti (2007), Tim Inflasi Bank Indonesia (2006). Seluruh penelitian tersebut lebih ditekankan pada persistensi inflasi nasional dan terbatas pada persistensi inflasi umum dan kelompok komoditas. Secara umum ditemukan bahwa derajat peristensi inflasi di Indonesia relatif tinggi pada periode pengamatan, meskipun terdapat kecenderungan menurun pada periode paska krisis tahun 1997/1998. Namun demikian, belum ada studi mengenai peristensi inflasi yang dilakukan ditingkat daerah dan mencakup hingga ke level komoditi pembentuk inflasi daerah dan nasional.

Studi yang dilakukan Alamsyah (2008) ditujukan untuk melihat perubahan perilaku inflasi di Indonesia pada masa sebelum dan sesudah krisis, serta melihat sumber penyebab persistensi inflasi, terutama yang berasal dari perilaku mikro pengusaha yang didekati dengan model hybrid NKPC. Dengan menggunakan pendekatan univariate, yaitu the sum of autoregressive coefficient (AR (1)) ditemukan bahwa derajat persistensi di Indonesia relatif tinggi pada periode pengamatan 1985-2007. Namun demikian, derajat persistensi tersebut cenderung menurun pada masa setelah krisis ekonomi. Ditemukan pula bahwa inflasi di Indonesia berperilaku campuran yang merupakan kombinasi dari perilaku backward dan forward looking. Oleh karena itu, upaya penjangkaran 
ekspektasi inflasi menuju ke target yang ditetapkan bank sentral diperlukan untuk mengendalikan inflasi dan meningkatkan kredibilitas kebijakan moneter di Indonesia.

Sementara itu, studi sebelumnya oleh Yanuarti (2007) bertujuan untuk mengukur derajat persistensi inflasi di Indonesia serta meneliti apakah terjadi perubahan derajat persistensi inflasi pada kurun waktu 1990-2006. Dengan menggunakan full sample, ditemukan bahwa derajat persistensi inflasi di Indonesia sangat tinggi, namun cenderung menurun pada periode setelah krisis. Temuan ini sejalan dengan temuan Alamsyah (2008).

\subsection{Penyebab Persistensi Inflasi}

Sumber tekanan inflasi dapat dilihat melalui persamaan New Keynesian Philips Curve (NKPC), dimana penyebab persistensi inflasi dapat dilihat berdasarkan perilaku inflasi yang melihat ke depan (forward looking) dan ke belakang (backward looking). Pendekatan ini merupakan pengembangan dari model awal inflasi yang menggambarkan dinamika inflasi sebagaimana tertuang dalam NKPC:

$$
\pi_{t}=\kappa y_{t}+\beta E_{t} \pi_{t+1}
$$

Selanjutnya, menurut Gali dan Gertler (1999), selain berorientasi forward looking, inflasi juga memiliki perilaku yang backward looking. Kedua perilaku tersebut tergambar dari model Hybrid NKPC yang menangkap karakteristik persistensi inflasi.

Persamaan struktural inflasi yang seringkali disebut sebagai hybrid New Keynesian Phillips Curve, tercakup dalam persamaan di bawah ini (Angeloni et. al, 2004) :

$$
\pi_{t}=\gamma_{b} \pi_{t-1}+\gamma_{f} E_{t}\left(\pi_{t+1}\right)-\lambda \hat{\mu}_{t}+\xi_{t}
$$

dimana adalah inflasi pada waktu $t ; E_{t}\left(\pi_{t+1}\right)$ adalah ekspektasi inflasi pada waktu $t+1$ dengan kondisi informasi pada waktu $t, \mu_{t}$ adalah output gap dan $\xi_{t}$ adalah unsur shock eksogen.

Dengan melihat sisi kanan dari persamaan tersebut, dapat diperkirakan empat sumber inflasi: (i) extrinsic persistence yang terkait dengan persistensi pada biaya marjinal ataupun output gap; (ii) intrinsic persistence yang terkait dengan dependensi inflasi terhadap inflasi periode sebelumnya (backward looking expectation); (iii) expectations-based persistence yang terkait dengan pembentukan ekspektasi inflasi yang didasarkan pada kondisi ke depan (forward looking); dan (iv) error term persistence akibat pengaruh kejutan sisi pasokan atau inflation shock yang terjadi. 


\section{METODOLOGI}

\subsection{Teknik Estimasi}

Estimasi persistensi inflasi dilakukan dengan melihat proses univariate autoregressive $(A R)$ time series model sebagaimana Marques (2004) karena model AR tersebut merupakan pengukur persistensi inflasi yang cukup baik serta berkaitan langsung dengan koefisien mean reversion sebagai alternatif pengukuran tingkat persistensi inflasi. Formula AR dengan order $p$ dapat dijabarkan sebagai berikut:

$$
\begin{aligned}
& \pi_{t}=\mu+\sum_{j=1}^{K} \alpha_{j} \pi_{t-j}+\varepsilon_{t} \\
& \pi_{t} \quad: \text { tingkat inflasi bulanan pada waktu t } \\
& \mu \quad: \text { konstanta dari hasil proses estimasi, sebagai kontrol terhadap rata-rata inflasi } \\
& \sum_{j=1}^{K} \alpha_{j} \quad \text { : jumlah koefisien AR } \\
& \varepsilon_{t} \quad: \text { random error term atau residual dari regresi persamaan di atas }
\end{aligned}
$$

Tingkat persistensi inflasi dihitung dengan menjumlahkan koefisien $\operatorname{AR}\left(\rho \equiv \sum_{j=1}^{K} \alpha_{j}\right)$. Persistensi inflasi dikatakan tinggi apabila tingkat inflasi saat ini sangat dipengaruhi oleh nilai lag-nya, sehingga koefisiennya mendekati 1. Dalam hal ini, inflasi dikatakan mendekati unit root process.

Untuk estimasi $\rho$, penentuan jumlah lag variable dependen yang sesuai menggunakan Akaike Information Criterion (AIC) dan atau Schwarz' Bayesian Information Criterion (SBIC). Untuk melihat robustness hasil yang diperoleh dilakukan pula prosedur bootstrap dan rolling regression. Tes structural breakdilakukan dengan menerapkan teknik seperti Quandt (1960) dan Chow testuntuk melakukan tes terhadap known dan unknown break. Untuk mengukur berapa lama waktu yang diperlukan inflasi dalam menyerap 50\% shock yang terjadi sebelum kembali ke nilai rata-ratanya, digunakan formula:

$$
h=\frac{\rho}{1-\rho}
$$

Dalam paper ini penyebab persistensi inflasi dapat dilihat berdasarkan perilaku inflasi yang melihat ke depan (forward looking) dan ke belakang (backward looking) sebagai berikut: 


$$
\pi_{t}=\gamma_{b} \pi_{t-1}+\gamma_{f} E_{t}\left(\pi_{t+1}\right)-\lambda \hat{\mu}_{t}+\xi_{t}
$$

dimana $\pi_{t}$ adalah inflasi pada waktu $t ; E_{t}\left(\pi_{t+1}\right)$ adalah ekspektasi inflasi pada waktu $t+1$ dengan kondisi informasi pada waktu $t, \mu_{t}$ adalah output gap dan $\xi_{t}$ adalah unsur shock eksogen. Variabel yang signifikan dan memiliki koefisien yang besar adalah variabel yang menjadi sumber utama tekanan inflasi. Berangkat dari analisis mengenai sumber tekanan inflasi tersebut, dilakukan analisis lebih lanjut untuk melihat sumber persistensi inflasi.

Dalam analisis sumber persistensi inflasi difokuskan hanya pada 5 komoditi yang memiliki derajat persistensi inflasi tertinggi. Lima komoditi tersebut merupakan komoditi yang sangat penting dalam pengendalian inflasi. Untuk menganalisis sumber persistensi inflasi digunakan anecdotal information dan analisis serta kajian yang pernah dilakukan terkait dengan komoditi tersebut. Informasi yang dikumpulkan antara lain mengenai struktur pasar dan karakteristik inflasi komoditi dimaksud.

\subsection{Data}

Data yang akan digunakan dalam analisis persistensi inflasi ini meliputi:

1. Inflasi bulanan (year-on-year), diukur dengan menggunakan Indeks Harga Konsumen (IHK)total seluruh kota di Indonesia (inflasi Nasional) dan IHK Kota Jakarta, serta IHK 9 daerah lainnya yang memiliki bobot terbesar terhadap inflasi nasional. Adapun data tersebut menggunakan tahun dasar 2002. IHK tersebut dapat dirinci ke dalam 7 (tujuh) kelompok komoditi yang meliputi: (i) Bahan makanan, (ii) Makanan jadi, minuman, rokok \& tembakau, (iii) Perumahan, (iv) Sandang, (v) Kesehatan, (vi) Pendidikan, rekreasi \& olah raga, dan (vii) Transportasi dan komunikasi. Rentang sampel yang digunakan dimulai sejak Januari 2000 Mei 2008 (Desember 2009 untuk nasional). Sumber data IHK diperoleh dari Biro Pusat Statistik dan International Financial Statistics (IFS).

2. Target inflasi tahunan (sumber: Bank Indonesia)

Penggunaan data inflasi year-on-year terutama dilatarbelakangi beberapa alasan sebagaimana yang pernah dikemukakan Babecky (2008) sebagai berikut:

1. Penggunaan data inflasi month-to-month (m-t-m) ataupun quarter-to-quarter (q-t-q) sangat terkait dengan faktor seasonal sehingga dikhawatirkan kurang dapat menggambarkan tingkat persistensi inflasi yang sebenarnya

2. Kedua ukuran inflasi tersebut $m-t-m$ dan $q-t-q$ bukan merupakan ukuran yang dimonitor oleh agen ekonomi tertentu 
3. Bank sentral dalam menentukan target inflasi lebih didasarkan pada perubahan inflasi tahunan $(y-o-y)$.

\section{HASIL DAN ANALISIS}

\subsection{Perkembangan Inflasi Jakarta}

Inflasi Jakarta memiliki pola yang hampir serupa dengan inflasi nasional.Dalam kurun waktu 25 tahun terakhir, rata-rata tingkat inflasi Jakarta tidak banyak mengalami perubahan yang signifikan. Baik pada periode sebelum dan setelah krisis ekonomi yang terjadi pada tahun 1997/1998, rata-rata inflasi cenderung bertahan pada kisaran angka 8\% (di luar periode krisis). Sementara itu, dibandingkan dengan negara-negara di kawasan seperti Malaysia, Thailand dan Filipina pada kurun waktu tersebut, inflasi Indonesia masih relatif lebih tinggi (Alamsyah, 2008). Kecenderungan bertahannya tingkat inflasi pada tingkat yang cukup tinggi tersebut perlu dicermati lebih jauh untuk dapat menentukan langkah-langkah yang tepat dalam pengendaliannya.

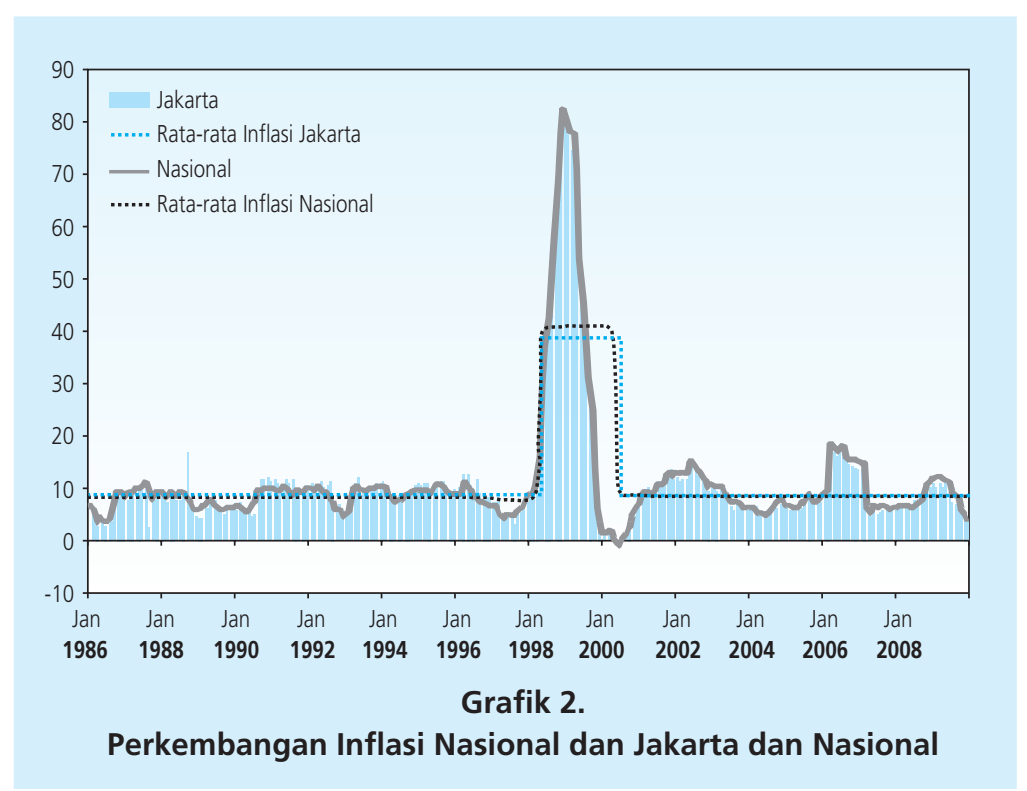

Cenderung tingginya tingkat inflasi Jakarta masih terlihat setelah penerapan ITF di Indonesia.Secara formal, ITF mulai diterapkan pada Juli 2005 dengan penetapan target inflasi secara berkala secara transparan. Grafik 3 menggambarkan bahwa realisasi inflasi baik Jakarta maupun Nasional masih seringkali tidak dapat mencapai target yang ditetapkan. Hal ini menggambarkan lambatnya proses penurunan inflasi di Indonesia. Level terendah inflasi tahunan 
hingga tahun 2008 yang dapat dicapai masih berada di atas 5\%. Jika dibandingkan dengan rata-rata inflasi negara yang telah mengadopsi ITF, tingkat inflasi di Indonesia tergolong masih relatif tinggi.

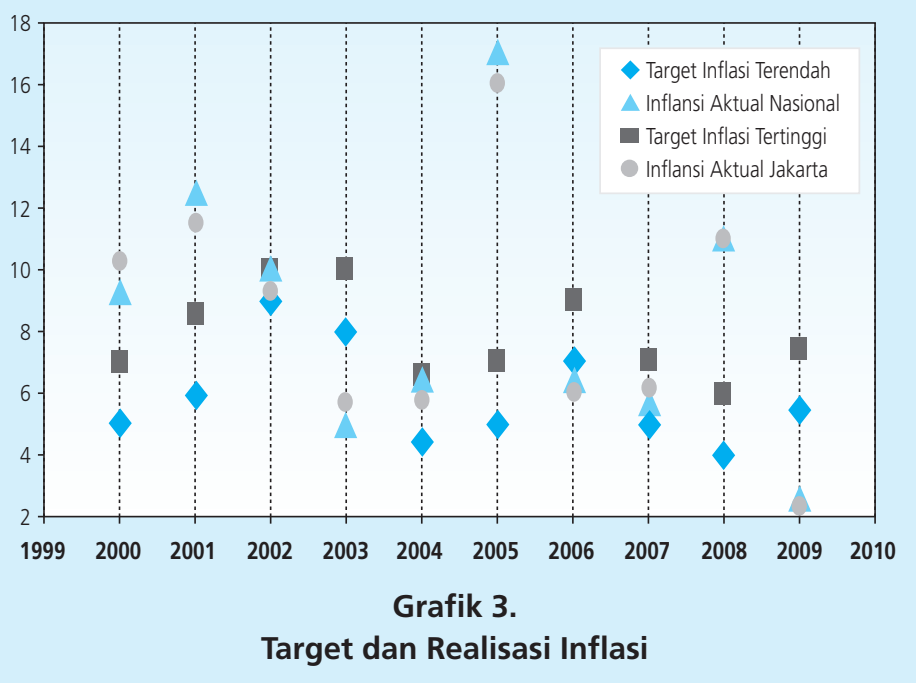

Perkembangan inflasi Jakarta juga menunjukkan pola yang hampir serupa dengan inflasi daerah lainnya di Indonesia. Perkembangan inflasi beberapa kota besar di Indonesia secara visual digambarkan pada Grafik 4.

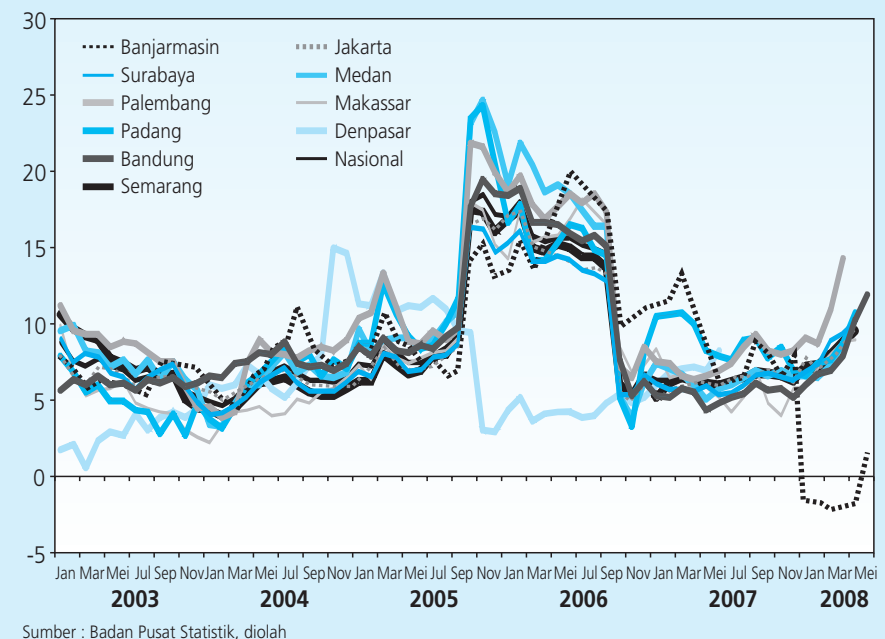

Grafik 4.

Inflasi Beberapa Kota Besar di Indonesia 
Secara statistik deskriptif, perbandingan perilaku inflasi Jakarta berdasarkan central tendency measurement seperti mean, trimmed mean dan median serta dispersi data berupa standar deviasi inflasi diperlihatkan pada Tabel 1. Dari ukuran-ukuran tersebut, perilaku inflasi Jakarta terlihat tidak jauh berbeda dengan inflasi nasional yang ditunjukkan pada Tabel 2.

\begin{tabular}{|c|c|c|c|c|c|c|c|c|c|c|c|c|c|}
\hline \multirow{2}{*}{ No } & \multirow{2}{*}{ Kelompok Komoditi } & \multicolumn{4}{|c|}{ Full Sampel } & \multicolumn{4}{|c|}{ Pra - ITF } & \multicolumn{4}{|c|}{ Paska - ITF } \\
\hline & & Mean & $\begin{array}{c}\text { Trimmed } \\
\text { mean }\end{array}$ & Median & SD & Mean & $\begin{array}{c}\text { Trimmed } \\
\text { mean }\end{array}$ & Median & SD & Mean & $\begin{array}{c}\text { Trimmed } \\
\text { mean }\end{array}$ & Median & SD \\
\hline & Umum & 8,48 & 8,44 & 7,13 & 3,75 & 7,89 & 7,98 & 7,05 & 3,29 & 9,59 & 9,51 & 7,65 & 4,32 \\
\hline & Kelompok Komoditi & & & & & & & & & & & & \\
\hline 1 & Bahan makanan & 8,66 & 8,61 & 9,75 & 5,16 & 6,19 & 6,08 & 5,79 & 4,27 & 13,31 & 13,36 & 12,83 & 3,06 \\
\hline 2 & Makanan jadi, minuman, rokok \& tembakau & 8,69 & 8,54 & 8,53 & 4,32 & 8,92 & 8,83 & 8,21 & 4,50 & 8,25 & 8,20 & 8,88 & 3,96 \\
\hline 3 & Perumahan & 8,80 & 8,79 & 8,84 & 2,38 & 9,13 & 9,12 & 9,30 & 1,77 & 8,19 & 8,15 & 7,89 & 3,18 \\
\hline 4 & Sandang & 6,58 & 6,51 & 6,63 & 2,86 & 5,96 & 5,89 & 6,18 & 2,80 & 7,74 & 7,71 & 7,81 & 2,63 \\
\hline 5 & Kesehatan & 6,07 & 5,69 & 4,46 & 3,64 & 6,32 & 5,97 & 4,37 & 4,28 & 5,59 & 5,57 & 5,43 & 1,91 \\
\hline 6 & Pendidikan, rekreasi \& olah raga & 9,17 & 8,63 & 7,96 & 6,41 & 10,41 & 10,04 & 8,38 & 7,51 & 6,84 & 6,82 & 6,47 & 2,07 \\
\hline 7 & Transport dan komunikasi & 11,23 & 10,26 & 9,44 & 10,22 & 10,38 & 10,17 & 10,28 & 5,58 & 12,83 & 12,38 & 1,41 & 15,60 \\
\hline
\end{tabular}

Sumber: Badan Pusat Statistik, diolah

Pada periode pengamatan full sample, rata-rata inflasi baik Jakarta maupun nasional berada pada level 8\%. Demikian pula jika diuraikan ditingkat kelompok komoditi, terlihat bahwa rata-ratanya masih mendekati level tersebut. Sementara itu, rata-rata inflasi baik secara umum maupun kelompok komoditi pada periode pra- dan paska-ITF tidak menunjukkan perbedaan yang signifikan. Hal ini menunjukkan bahwa inflasi di Indonesia masih menunjukkan perilaku

\begin{tabular}{|c|c|c|c|c|c|c|c|c|c|c|c|c|c|}
\hline \multirow{2}{*}{ No } & \multirow{2}{*}{ Kelompok Komoditi } & \multicolumn{4}{|c|}{ Full Sampel } & \multicolumn{4}{|c|}{ Pra - ITF } & \multicolumn{4}{|c|}{ Paska - ITF } \\
\hline & & Mean & $\begin{array}{c}\text { Trimmed } \\
\text { mean }\end{array}$ & Median & SD & Mean & $\begin{array}{c}\text { Trimmed } \\
\text { mean }\end{array}$ & Median & SD & Mean & $\begin{array}{c}\text { Trimmed } \\
\text { mean }\end{array}$ & Median & SD \\
\hline & Umum & 8,36 & 8,31 & 7,40 & 4,06 & 7,80 & 7,91 & 7,36 & 3,49 & 9,04 & 8,94 & 7,45 & 4,61 \\
\hline & Kelompok Komoditi & & & & & & & & & & & & \\
\hline 1 & Bahan makanan & 8,34 & 8,64 & 8,61 & 6,58 & 4,80 & 5,02 & 6,25 & 5,78 & 12,67 & 12,71 & 12,38 & 4,65 \\
\hline 2 & Makanan jadi, minuman, rokok \& tembakau & 8,98 & 8,94 & 8,79 & 3,29 & 8,76 & 8,68 & 8,79 & 3,86 & 9,25 & 9,19 & 8,78 & 2,44 \\
\hline 3 & Perumahan & 8,94 & 8,98 & 8,66 & 5,12 & 9,89 & 9,91 & 9,83 & 2,96 & 7,78 & 7,72 & 6,61 & 6,76 \\
\hline 4 & Sandang & 7,06 & 6,98 & 6,16 & 2,62 & 6,74 & 6,63 & 5,61 & 2,87 & 7,46 & 7,43 & 7,16 & 2,24 \\
\hline 5 & Kesehatan & 6,10 & 5,94 & 5,76 & 2,01 & 6,57 & 6,44 & 6,21 & 2,40 & 5,52 & 5,51 & 5,35 & 1,19 \\
\hline 6 & Pendidikan, rekreasi \& olah raga & 8,88 & 8,91 & 8,71 & 2,74 & 10,33 & 10,41 & 10,27 & 2,32 & 7,11 & 7,12 & 7,99 & 2,09 \\
\hline 7 & Transport dan komunikasi & 9,85 & 8,97 & 6,18 & 11,11 & 9,96 & 9,73 & 9,39 & 5,67 & 9,71 & 8,98 & 1,42 & 15,42 \\
\hline
\end{tabular}

Sumber: Badan Pusat Statistik, diolah 
yang cenderung persisten paska-ITF. Di samping itu, volatilitas inflasi di kedua periode tersebut juga tidak banyak mengalami perubahan. Adanya shock pada kelompok transportasi dan komunikasi yang dipicu oleh kenaikan harga BBM pada tahun 2005 menjadi salah satu penyebab tingginya standar deviasi inflasi di kelompok tersebut.

\subsection{Pengukuran Derajat Persistensi Inflasi Jakarta ${ }^{2}$}

Pemilihan komoditi ditentukan berdasarkan rata-rata sumbangan inflasi terbesar terhadap pembentukan inflasi IHK Jakarta dalam 5 tahun terakhir. Dari sekitar 774 komoditi (termasuk kelompok/sub kelompok komoditi) pembentuk keranjang IHK Jakarta, dipilih 28 jenis komoditi yang mewakili $66,35 \%$ dari rata-rata inflasi Jakarta pada periode tersebut. Beras, bensin, angkutan dalam kota, kontrak rumah, sewa rumah, tarif PAM dan minyak tanah merupakan komoditi yang sumbangan inflasinya terbesar dibandingkan dengan komoditi lainnya. Besarnya sumbangan inflasi masing-masing komoditi tersebut dicantumkan pada Tabel 3.

\begin{tabular}{|c|c|c|c|c|c|}
\hline \multicolumn{6}{|c|}{$\begin{array}{l}\text { Tabel } 3 . \\
\text { Kontribusi Komoditi Terpilih Pembentuk Inflasi Jakarta }\end{array}$} \\
\hline No & $\begin{array}{l}\text { Komoditi Jakarta } \\
\text { Umum/total }\end{array}$ & $\begin{array}{c}\text { Kontribusi } \\
8,12\end{array}$ & No & Komoditi Jakarta & Kontribusi \\
\hline 1 & Beras & 0,65 & 15 & Gas elpiji & 0,09 \\
\hline 2 & Daging ayam ras & 0,07 & 16 & Minyak tanah & 0,31 \\
\hline 3 & Daging sapi & 0,04 & 17 & Tarif PAM & 0,33 \\
\hline 4 & Tempe & 0,05 & 18 & Tarif listrik & 0,21 \\
\hline 5 & Cabe & 0,03 & 19 & Upah pembantu & 0,11 \\
\hline 6 & Minyak goreng & 0,07 & 20 & Emas & 0,16 \\
\hline 7 & Ayam goreng & 0,08 & 21 & Tarif RS & 0,03 \\
\hline 8 & Mie & 0,09 & 22 & SD & 0,09 \\
\hline 9 & Gula pasir & 0,07 & 23 & SLTP & 0,08 \\
\hline 10 & Rokok kretek & 0,06 & 24 & SLTA & 0,08 \\
\hline 11 & Rokok kretek filter & 0,09 & 25 & PT & 0,12 \\
\hline 12 & Kontrak rumah & 0,83 & 26 & Angkutan antar kota & 0,07 \\
\hline 13 & Sewa rumah & 0,23 & 27 & Angkutan dalam kota & 0,72 \\
\hline 14 & Tukan bukan mandor & 0,16 & 28 & Bensin & 0,48 \\
\hline
\end{tabular}

Sumber: Badan Pusat Statistik, diolah

2 Waktu penerapan ITF secara formal di Indonesia dimulai sejak Juli 2005 (website Bank Indonesia: www.bi.go.id). Di penelitian lain oleh Harmanta (2009), periode sampai dengan Juni 2005 disebut sebagai Lite-ITF dan sejak Juli 2005 sebagai Full-ITF. 


\begin{tabular}{|c|c|c|c|c|}
\hline \multirow{4}{*}{ No } & \multirow{2}{*}{ Komoditi } & \multicolumn{3}{|c|}{ Derajat Persistensi Inflasi Jakarta* } \\
\hline & & OLS & Bootstrap & Rolling Regression \\
\hline & Umum & 0,94 & 0,79 & 0,90 \\
\hline & Kelompok Komoditi & & & \\
\hline 1 & Bahan makanan & 0,98 & 0,84 & 0,86 \\
\hline 2 & Makanan jadi, minuman, rokok \& tembakau & 0,92 & 0,83 & 0,92 \\
\hline 3 & Perumahan & 0,84 & 0,61 & 0,80 \\
\hline 4 & Sandang & 0,88 & 0,73 & 0,87 \\
\hline 5 & Kesehatan & 0,93 & 0,87 & 0,89 \\
\hline 6 & Pendidikan, rekreasi \& olah raga & 0,90 & 0,73 & 0,77 \\
\hline \multirow[t]{2}{*}{7} & Transport dan komunikasi & 0,90 & 0,74 & 0,86 \\
\hline & Komoditi & & & \\
\hline 1 & Beras & 0,94 & 0,88 & 0,93 \\
\hline 2 & Daging ayam ras & 0,68 & 0,35 & 0,49 \\
\hline 3 & Daging sapi & 0,93 & 0,82 & 0,91 \\
\hline 4 & Tempe & 0,61 & 0,86 & 0,81 \\
\hline 5 & Cabe & 0,72 & 0,37 & 0,68 \\
\hline 6 & Minyak goreng & 0,94 & 0,78 & 0,85 \\
\hline 7 & Ayam goreng & 0,80 & 0,67 & 0,65 \\
\hline 8 & Mie & 0,69 & 0,40 & 0,64 \\
\hline 9 & Gula pasir & 0,90 & 0,78 & 0,88 \\
\hline 10 & Rokok kretek & 0,78 & 0,87 & 0,83 \\
\hline 11 & Rokok kretek filter & 0,61 & 0,72 & 0,84 \\
\hline 12 & Kontrak rumah & 0,90 & 0,73 & 0,86 \\
\hline 13 & Sewa rumah & 0,92 & 0,80 & 0,85 \\
\hline 14 & Tukan bukan mandor & 0,84 & 0,51 & 0,70 \\
\hline 15 & Gas elpiji & 0,78 & 0,50 & 0,93 \\
\hline 16 & Minyak tanah & 0,76 & 0,78 & 0,89 \\
\hline 17 & Tarif PAM & 0,87 & 0,51 & 0,73 \\
\hline 18 & Tarif listrik & 0,82 & $\mathrm{n} / \mathrm{a}$ & $\mathrm{n} / \mathrm{a}$ \\
\hline 19 & Upah pembantu & 0,97 & 0,77 & 0,80 \\
\hline 20 & Emas & 0,90 & 0,61 & 0,82 \\
\hline 21 & Tarif RS & 0,80 & 0,69 & 0,73 \\
\hline 22 & SD & 0,73 & 0,59 & 0,80 \\
\hline 23 & SLTP & 0,80 & 0,61 & 0,82 \\
\hline 24 & SLTA & 0,90 & 0,74 & 0,70 \\
\hline 25 & PT & 0,88 & 0,90 & 0,89 \\
\hline 26 & Angkutan antar kota & 0,84 & 0,63 & 0,86 \\
\hline 27 & Angkutan dalam kota & 0,88 & 0,55 & 0,67 \\
\hline 28 & Bensin & 0,74 & 0,78 & 0,86 \\
\hline
\end{tabular}

* Penentuan lag optimum berdasarkan kriteria SBIC, AIC, HQIC

Sumber: Badan Pusat Statistik, diolah 
Disamping pengukuran derajat persistensi inflasi hingga ke level komoditi dominan pembentuk inflasi di Jakarta, dilakukan pula pengukuran tingkat persistensi inflasi IHK berdasarkan disagregasinya, yang terbagi menjadi inflasi inti, inflasi volatile food dan inflasi administered price.

Hasil estimasi derajat persistensi inflasi di wilayah Jakarta berdasarkan kelompok komoditi dan komoditi pembentuk IHK Jakarta disajikan pada Tabel 4. Derajat persistensi inflasi tersebut diperoleh dengan menjumlahkan seluruh koefisien AR sesuai dengan lag optimum inflasi masingmasing komoditi/kelompok komoditi. Penentuan lag optimum dilakukan dengan menggunakan kriteria AIC/HQIC/SBIC. Pengukuran derajat persistensi inflasi Jakarta dengan menggunakan 3 teknik yang berbeda menunjukkan hasil yang tidak jauh berbeda, meskipun teknik OLS dan rolling regression memperlihatkan hasil estimasi yang lebih dekat dibandingkan dengan OLS dan bootstrap.

Dengan menggunakan full sample, hasil estimasi derajat persistensi Jakarta secara umum menunjukkan bahwa inflasi IHK Jakarta masih sangat persisten. Hal ini sejalan dengan persistensi inflasi nasional yang pada periode pengamatan yang sama juga menunjukkan angka persistensi yang tinggi ${ }^{3}$. Dari 7 kelompok komoditi pembentuk IHK, hampir seluruhnya menunjukkan derajat persistensi inflasi yang tinggi. Hanya kelompok perumahan yang tingkat persistensi inflasinya tidak setinggi kelompok komoditi lainnya.

Hasil estimasi juga menunjukkan bahwa derajat persistensi inflasi kelompok bahan makanan yang karakteristiknya inflasinya banyak dipengaruhi oleh shock gangguan pasokan dan distribusi terlihat masih cukup tinggi. Sementara itu, kelompok komoditi yang persistensi inflasinya tertinggi yang secara konsisten ditunjukkan oleh hasil estimasi ketiga pendekatan pada Tabel 4 adalah kelompok makanan jadi, minuman, rokok dan tembakau dan kelompok kesehatan. Di tingkat komoditas, beras, daging sapi, minyak goreng, gula pasir, kontrak rumah, dan sewa rumah merupakan beberapa komoditi yang tertinggi tingkat persistensi inflasinya dibandingkan dengan komoditi terpilih lainnya.

Tingginya derajat persistensi inflasi tersebut diperkirakan terkait dengan shocks yang banyak memengaruhi perkembangan inflasi di Indonesia pada umumnya. Untuk itu, perlu dilakukan uji untuk melihat apakah terdapat structural break pada data inflasi.Quandt-Andrews test terhadap series inflasi dilakukan untuk melihat apakah terdapat structural break selama periode pengamatan. Berdasarkan hasil tes tersebut, terdapat structural break di series data inflasi umum dan beberapa kelompok komoditi (kelompok perumahan, kelompok pendidikan,

3 Sebagaimana hasil pengukuran derajat persistensi inflasi nasional yang disajikan pada Tabel 4. 
rekreasi \& olah raga, dan kelompok transportasi dan komunikasi) serta komoditi (tempe, rokok kretek, rokok kretek filter, gas elpiji, minyak tanah dan SLTA), disajikan pada Tabel 5.

Setelah mengakomodir structural break pada series data inflasi Jakarta, derajat persistensi inflasi menunjukkan sedikit perbedaan. Beberapa komoditi memperlihatkan penurunan derajat persistensi inflasi, namun beberapa komoditi lainnya menunjukkan peningkatan. Dengan demikian, untuk Jakarta, keberadaan structural break tidak selalu menyebabkan pengukuran derajat persistensi inflasi yang berlebihan.

\begin{tabular}{|c|c|c|c|}
\hline \multirow{2}{*}{ No } & \multirow{2}{*}{ Komoditi } & \multicolumn{2}{|c|}{ Derajat Persisitensi Inflasi Jakarta } \\
\hline & & Tanpa SB & Dengan SB \\
\hline 1 & Umum & 0,94 & 0,93 \\
\hline 2 & Perumahan & 0,84 & 0,83 \\
\hline 3 & Pendidikan, rekreasi \& olah raga & 0,90 & 0,87 \\
\hline 4 & Transport dan komunikasi & 0,90 & 0,92 \\
\hline 5 & Tempe & 0,61 & 0,92 \\
\hline 6 & Rokok kretek & 0,78 & 0,86 \\
\hline 7 & Rokok kretek filter & 0,61 & 0,60 \\
\hline 8 & Gas elpiji & 0,78 & 0,86 \\
\hline 9 & Minyak tanah & 0,76 & 0,96 \\
\hline 10 & SLTA & 0,90 & 0,86 \\
\hline
\end{tabular}

Sumber: Badan Pusat Statistik, diolah

Tingginya derajat persistensi inflasi Jakarta tercermin pula dari lamanya waktu yang dibutuhkan oleh inflasi untuk menyerap 50\% shock yang terjadi sebelum kembali ke nilai rataratanya. Dengan melihat hasil estimasi OLS, waktu yang dibutuhkan oleh kelompok komoditi mencapai 5 sampai 13 bulan. Kelompok komoditi dengan derajat persistensi inflasi tertinggi adalah kelompok makanan jadi, minuman, rokok dan tembakau dan kelompok transport dan komunikasi yang memerlukan waktu kurang lebih 12 bulan sebelum kembali ke nilai rataratanya. Sementara kelompok kesehatan memerlukan waktu sekitar 13 bulan. Ketiga kelompok tersebut merupakan kelompok komoditi dengan derajat persistensi inflasi tertinggi yang secara konsisten ditunjukkan oleh 3 teknik pengukuran yang digunakan. Meskipun estimasi OLS yang digambarkan pada Grafik 4 menghasilkan derajat persistensi inflasi yang sangat tinggi untuk kelompok bahan makanan, hasil tersebut tidak didukung oleh 2 teknik lainnya. 


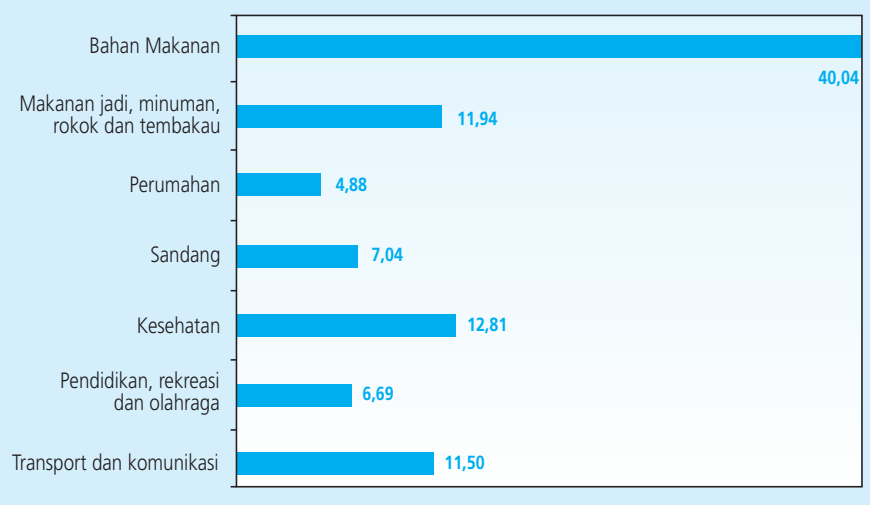

Sumber : Badan Pusat Statistik, diolah

Grafik 5. Waktu yang Dibutuhkan Inflasi Kelompok Komoditi Kembali ke Nilai Rata-rata (Bulan) - Jakarta (Setelah mengakomodir structural break)

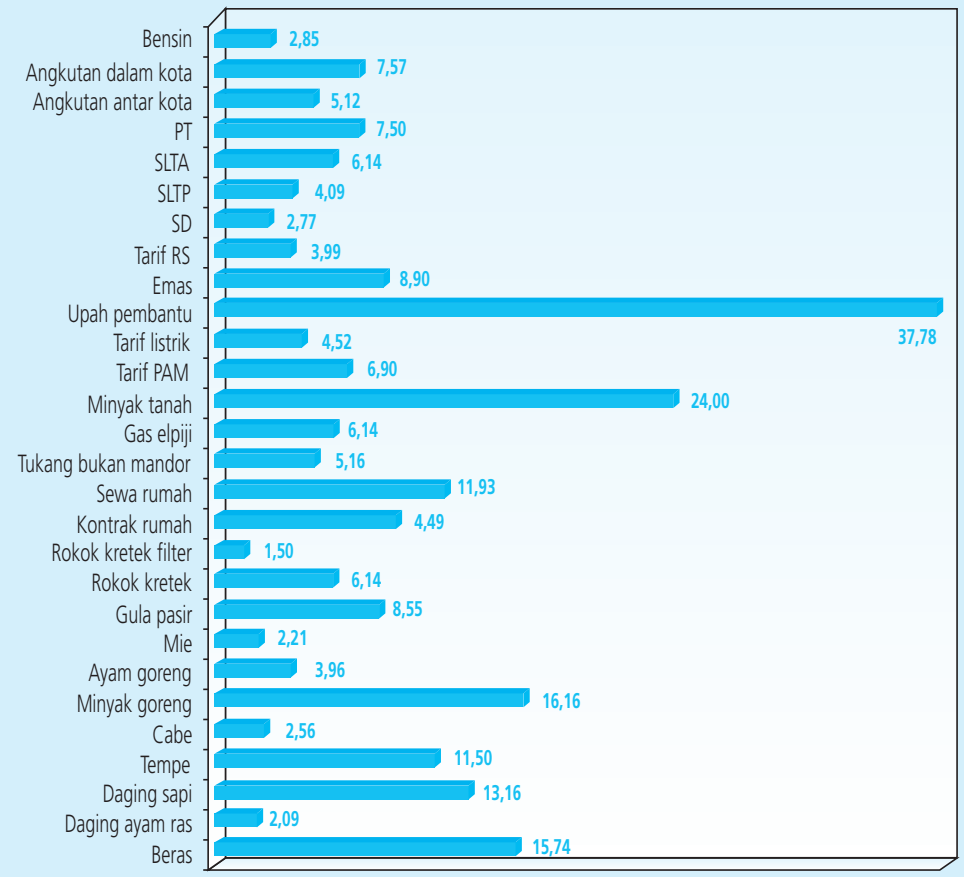

Sumber : Badan Pusat Statistik, diolah

Grafik 6. Waktu yang Dibutuhkan Inflasi Komoditi

Kembali ke Nilai Rata-rata (Bulan) - Jakarta

(Setelah mengakomodir structural break) 
Dilihat dari komoditi pembentuk keranjang IHK, komoditi yang menunjukkan persistensi tertinggi adalah beras, daging sapi, minyak goreng, gula pasir, kontrak rumah dan sewa rumah. Sementara itu, komoditi yang memperlihatkan derajat persistensi terendah sebagian besar berasal dari kelompok bahan makanan, seperti daging ayam ras dan cabe. Disamping itu, mie yang termasuk dalam kelompok makanan jadi juga memperlihatkan tingkat persistensi yang relatif paling rendah dibandingkan dengan komoditi terpilih lainnya. Waktu yang dibutuhkan inflasi komoditi kembali ke rata-ratanya juga mendukung hasil pengukuran derajat persistensi tersebut (Grafik 6).

\begin{tabular}{|c|c|c|c|c|}
\hline \multirow{2}{*}{ No } & \multirow{2}{*}{ Komoditi } & \multicolumn{3}{|c|}{ Derajat Persistensi Inflasi Jakarta* } \\
\hline & & OLS & Bootstrap & Rolling Regression \\
\hline 1 & Inflasi IHK & 0,89 & 0,74 & 0,91 \\
\hline 2 & Inflasi Inti & 0,88 & 0,69 & 0,89 \\
\hline 3 & Inflasi Administered Price & 0,89 & 0,72 & 0,89 \\
\hline 4 & Inflasi Volatile Food & 0,92 & 0,81 & 0,86 \\
\hline
\end{tabular}

* Penentuan lag optimum berdasarkan kriteria SBIC, AIC, HQIC

Sumber: Badan Pusat Statistik, diolah

Dilihat berdasarkan disagregasinya, inflasi Jakarta terbagi menurut inflasi inti, inflasi administered price, dan inflasi volatile food. Tabel 6 mencantumkan hasil estimasi derajat persistensi inflasi Jakarta dengan menggunakan 3 teknik yaitu OLS, bootstrap dan rolling regression. Ketiga jenis inflasi tersebut masih sangat persisten pada periode pengamatan, terlihat

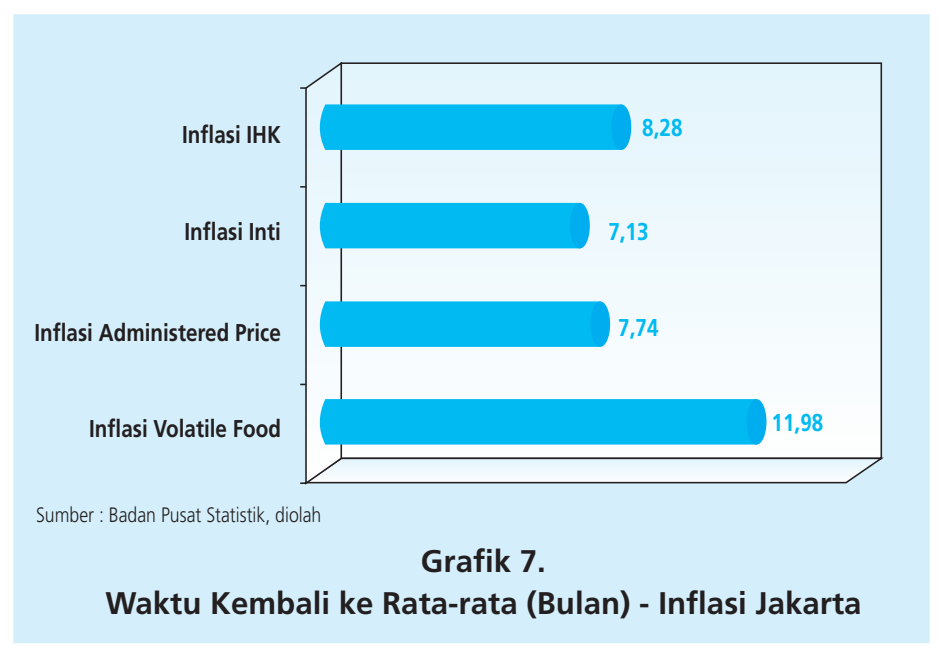


dari derajat persistensi inflasi yang tergolong masih tinggi (0.88 - 0.92), sehingga untuk kembali ke rata-ratanya membutuhkan waktu antara 7-12 bulan (Grafik 7).

Gambaran pemetaan hasil estimasi derajat persistensi inflasi yang telah dilakukan dengan menggunakan full sample dan tingkat inflasi masing-masing komoditi ditampilkan pada Gambar 1.

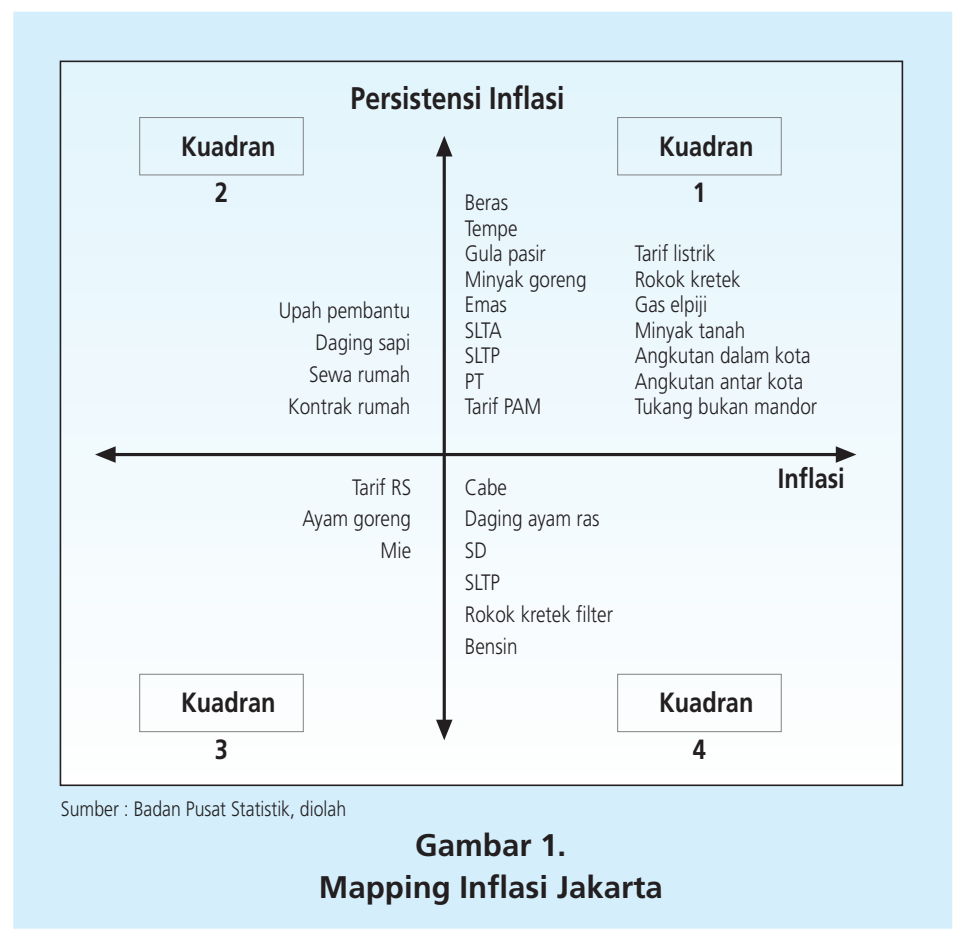

Di kuadran 1 adalah komoditi dengan tingkat persistensi inflasi tinggi dan inflasi tinggi, di kuadran 2 adalah komoditi dengan dengan tingkat persistensi inflasi tinggi dan inflasi rendah, di kuadran 3 adalah komoditi dengan dengan tingkat persistensi inflasi rendah dan inflasi rendah, dan di kuadran 4 adalah komoditi dengan dengan tingkat persistensi inflasi rendah dan inflasi tinggi. Penggolongan ke dalam tiap kuadran didasarkan pada kategori inflasi tinggi apabila tingkat inflasi $>10 \%$ dan persistensi inflasi tinggi apabila $>0,80$. Berdasarkan pemetaan tersebut, perhatian lebih perlu diarahkan kepada komoditi-komoditi yang terletak di kuadran 1. Namun demikian, komoditi-komoditi tersebut sebagian merupakan komoditi administered price yang harganya dipengaruhi oleh kebijakan pemerintah, seperti tarif listrik, tarif PAM, rokok kretek, gas elpiji, minyak tanah, angkutan dalam kota, angkutan antar kota. Hal ini mengimplikasikan perlunya koordinasi yang lebih baik antara pemerintah dengan bank sentral dalam upaya pengendalian inflasi di daerah. 


\subsection{Penyebab Persistensi Inflasi Jakarta}

Pendekatan lain untuk melihat penyebab peristensi inflasi adalah dengan menggunakan model Hybrid New Keynesian Philips Curve, mengikuti beberapa penelitian terdahulu, antara lain oleh Alamsyah (2008) dan Mehrotra et al (2007). Dengan metode ini, penyebab persistensi inflasi dilihat berdasarkan perilaku inflasi yang melihat ke depan (forward looking) dan ke belakang (backward looking). Kedua perilaku tersebut tergambar dari model Hybrid NKPC yang menangkap karakteristik persistensi inflasi sebagai berikut:

$$
\pi_{t}=\kappa y_{t}+\beta E_{t} \pi_{t+1}+\mu \pi_{t-1}+\varepsilon_{t}
$$

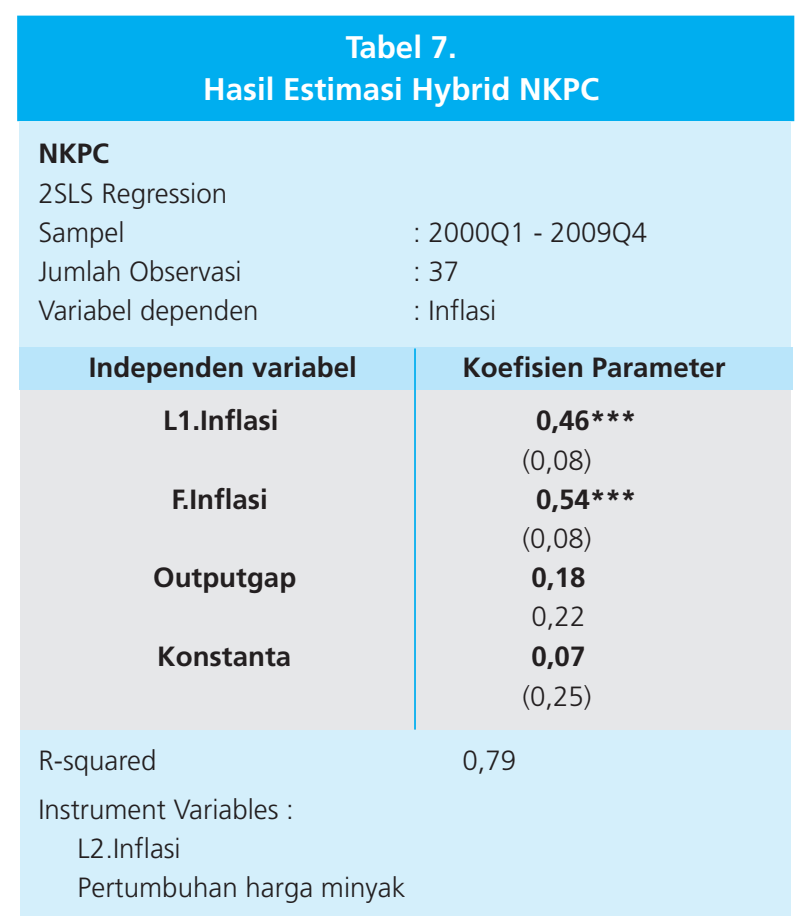

Estimasi model hybrid NKPC dilakukan dengan menggunakan teknik 2SLS (Two Stages Least Squares), dengan menambahkan restriksi parameter inflasi sehingga menjadi sama dengan 1. Hasil estimasi yang disajikan pada Tabel 7 menunjukkan bahwa inflasi Jakarta pada periode pengamatan berperilaku campuran, dipengaruhi oleh ekspektasi inflasi ke depan (forward looking) dan ke belakang (backward looking). Hal ini ditunjukkan oleh magnitude kedua parameter yang hampir seimbang menandakan bahwa pengaruh ekspektasi forwad dan backward looking tidak jauh berbeda. Disamping itu, pengujian dengan menggunakan Wald test juga menunjukkan bahwa tidak terdapat perbedaan yang signifikan antara koefisien 
forward dan backward looking inflasi Jakarta. Kondisi tersebut memperlihatkan perlunya upaya yang lebih intensif untuk mengubah perilaku ekspektasi inflasi ke arah forward looking.

Sementara itu, data output gap diperoleh dengan menggunakan teknik HP filter. Untuk Jakarta, terlihat bahwa parameter output gap tidak cukup signifikan memengaruhi inflasi Jakarta. Dengan demikian, pengaruh output gap terhadap inflasi belum dapat disimpulkan.

Inflasi yang tinggi menimbulkan dampak negatif terhadap perekonomian. Inflasi yang tinggi akan memberikan ketidakpastian bagi pelaku ekonomi dalam mengambil keputusan selain akan memengaruhi daya beli masyarakat terutama yang berpendapatan tetap. Pengelolaan ekonomi akan menjadi lebih sulit bila tingkat inflasi yang terbentuk menjadi persisten. Sesuai dengan salah satu definisi mengenai persistensi inflasi, laju inflasi akan membutuhkan waktu yang lebih lama untuk kembali kepada tingkat sebelum terjadi kejutan (shock). Demikian pula dengan proses konvergensi inflasi yang memerlukan waktu lebih lama. Hal tersebut dapat berimplikasi terhadap besarnya upaya yang diperlukan untuk menurunkan tingkat inflasi.

Persistensi inflasi yang tinggi di Jakarta memberikan implikasi bahwa upaya penurunan inflasi nasional akan menjadi tantangan yang lebih besar mengingat kota Jakarta memiliki bobot yang terbesar dalam pembentukan inflasi nasional.

Berdasarkan hasil asesmen, tingginya derajat persistensi inflasi di Jakarta antara lain diakibatkan oleh tingginya derajat persistensi inflasi yang terjadi pada kelompok volatile food dan kelompok administered price. Hal ini berimplikasi pada diperlukannya koordinasi yang lebih kuat antara Pemerintah dengan Bank Indonesia untuk mengendalikan inflasi. Sementara untuk kelompok administered price sangat bergantung pada upaya Pemerintah untuk mengatur timing dan magnitude kebijakan di bidang harga (dan pendapatan) sehingga memberikan dampak yang minimal terhadap inflasi.

Inflasi volatile food dan administered price yang tinggi akan mempengaruhi ekspektasi inflasi sehingga dapat mempersulit upaya pengendalian inflasi daerah. Koordinasi yang baik melalui forum-forum koordinasi yang telah ada seperti rapat koordinasi Dewan Gubernur BI dengan Pemerintah, forum penetapan sasaran inflasi, serta Tim Pengendalian Inflasi ke depan perlu lebih dioptimalkan lagi. Terkait dengan Tim Pemantauan dan Pengendalian Inflasi Daerah (TPID), target pembentukannya diseluruh daerah di Indonesia (mencakup 66 kota) perlu dipantau agar dapat terealisasi, mengingat pentingnya peranan pengendalian inflasi daerah untuk mencapai inflasi nasional yang rendah dan stabil.

Di samping itu, peran TPID dapat dioptimalkan perannya apabila dilakukan pula dengan koordinasi lintas wilayah (antar daerah), terutama dengan daerah yang memiliki keterikatan ekonomi yang besar. Disamping itu, perannya dalam pengembangan sistem informasi (data 
base) yang baik untuk kepentingan pemantauan komoditas penyumbang inflasi terbesar perlu direalisasikan sehingga dapat dimanfaatkan lebih jauh untuk penentuan kebijakan harga di tingkat daerah.

Upaya pengendalian inflasi di daerah selanjutnya diharapkan dapat memberikan dampak positif terhadap proses konvergensi inflasi antar daerah yang lebih cepat, sehingga pengendalian inflasi daerah dapat lebih mudah dilakukan. Kebijakan pengendalian inflasi melalui kebijakan moneter di tingkat nasional pada gilirannya diharapkan mampu menjadi semakin efektif. Isu konvergensi dan koordinasi pengendalian inflasi lintas daerah ini, khususnya kota Jakarta dengan daerah lain, akan menjadi topik yang menarik untuk diangkat dalam paper selanjutnya ${ }^{4}$.

Sementara itu, sumber tekanan inflasi dari ekspektasi inflasi yang masih dipengaruhi secara signifikan oleh ekspektasi backward looking memberikan implikasi perlunya diseminasi informasi dan kebijakan yang lebih intensif untuk mengarahkan ekspektasi inflasi menjadi lebih ke arah forward looking, agar tingkat inflasi dapat diturunkan ke tingkat yang rendah dan stabil. Upaya tersebut tidak terlepas dari kredibilitas otoritas penentu kebijakan yang senantiasa perlu dipelihara dan ditingkatkan.

\section{KESIMPULAN}

Penelitian ini memberikan beberapa kesimpulan penting, pertama, pengujian empiris menunjukkan bahwa inflasi IHK Jakarta memiliki derajat persistensi yang tinggi. Demikian pula jika dilihat berdasarkan disagregasinya, inflasi administered price, dan inflasi volatile fooddi Jakarta tergolong masih sangat persisten pada periode pengamatan. Kelompok komoditi yang tertinggi derajat persistensinya adalah kelompok makanan jadi, minuman, rokok \& tembakau dan kelompok kesehatan. Sedangkan ditingkat komoditas adalah beras, daging sapi, minyak goreng, gula pasir, kontrak rumah, dan sewa rumah. Tingginya derajat persistensi inflasi Jakarta tercermin pula dari lamanya waktu yang dibutuhkan oleh inflasi untuk menyerap 50\% shock yang terjadi sebelum kembali ke nilai rata-ratanya. Di Jakarta, kelompok komoditi sebagian besar membutuhkan waktu antara 5-12 bulan untuk kembali ke rata-ratanya sebelum terjadinya shock, sementara untuk komoditi sebagian besar membutuhkan waktu antara 3-12 bulan.

Kesimpulan kedua, dengan mengacu pada hasil estimasi model hybrid NKPC, ditemukan bahwa inflasi Jakarta berperilaku campuran, yang merupakan kombinasi antara perilaku forward dan backward looking. Hal ini sejalan dengan hasil penelitian perilaku inflasi nasional oleh Alamsyah (2008).

4 Arimurti dan Trisnanto, "Konvergensi inflasi antar daerah di Indonesia", forthcoming paper. 
Kesimpulan ketiga, penelitian ini menunjukkan bahwa penyebab tingginya derajat persistensi inflasi di Jakarta antara lain diakibatkan oleh tingginya derajat persistensi inflasi kelompok volatile food dan kelompok administered price. Inflasi volatile food dan administered price yang tinggi memengaruhi ekspektasi inflasi sehingga hal tersebut dapat mempersulit upaya pengendalian inflasi daerah.

Temuan di atas memiliki implikasi kebijakan yakni perlunya diseminasi informasi dan kebijakan yang lebih intensif untuk mengarahkan ekspektasi inflasi menjadi lebih ke arah forward looking, agar tingkat inflasi dapat diturunkan ke tingkat yang rendah dan stabil. Selain itu, temuan ini juga berimplikasi terhadap perlunya pengoptimalan koordinasi melalui forum-forum koordinasi yang telah ada seperti rapat koordinasi Dewan Gubernur BI dengan Pemerintah, forum penetapan sasaran inflasi, serta Tim Pengendalian Inflasi. 


\section{DAFTAR PUSTAKA}

Alamsyah, H. (2008). Persistensi Inflasi dan Dampaknya terhadap Pilihan dan Respons Kebijakan Moneter di Indonesia. Dissertation .

Angeloni, I., Aucremanne, L., Ehrmann, M., Gali, J., Levin, A., \& Smets, F. (2004). Inflation Persistence in the Euro Area : Preliminary Summary of Findings.

Babecky, J., Corricelly, F., \& Horvath, R. (2008, June). Assessing Inflation Peristence: Micro Evidence on an Inflation Targeting Economy. CERGE-El .

Batini, N. (2002, December). Euro Area Inflation Persistence. European Central Bank Working Paper Series .

Debelle, G., \& Wilkinson, J. (2002). Inflation Targeting and the Inflation Process: Some Lessons from an Open Economy. Research Bank of Australia - Research Discussion Paper 2002-01 . Dossche, M., \& Everaert, G. (2005, June). Measuring Inflation Persistence: A Structural Time Series Approach. National Bank of Belgium Working Paper .

Federal Reserve Bank of San Fransisco. (2006, October 13). Inflation Persistence in an Era of Well-Anchored Inflation Expectations. FRBSF Economic Letter .

Harmanta. (2009). Kredibilitas Kebijakan Moneter dan Dampaknya terhadap Persistensi Inflasi dan Strategi Disinflasi di Indonesia: dengan Model Dynamic Stochastic General Equilibrium (DSGE). Jakarta: Fakultas Ekonomi Program Pascasarjana Ilmu Ekonomi Universitas Indonesia. Levin, A. T., \& Piger, J. M. (2004, April). Is Inflation Persistence Intrinsic in Industrial Economies? European Central Bank Working Paper Series .

Marques, C. R. (2005). Inflation Peristence: Facts or Artefacts? Economic Bulletin .

Marques, C. R. (2004, June). Inflation Persistence: Facts or Artefacts? European Central Bank Working Paper Series.

O'Reilly, G., \& Whelan, K. (2004, April). Has Euro-Area Inflation Persistence Change Over Time? European Central Bank Working Paper Series .

Pivetta, F., \& Reis, R. (2006). The Persistence of Inflation in the United States. Journal of Economic Dynamics and Control , April.

Stock, J. H. (2004, December). Inflation Persistence in the Euro Area: Evidence from Aggregate and Sectoral Data.

Tim Inflasi. (2007). Persistensi Inflasi Inti. Isu Strategis. Bahan Rapat Dewan Gubernur 4 Januari. Jakarta: Bank Indonesia.

Willis, J. L. (2003). Implications of Structural Changes in the U.S. Economy for Pricing Behavior and Inflation Dynamics. Federal Reserve Bank of Kansas City Economic Review .

Yanuarti, T. (2007). Has Inflation Persistence in Indonesia Changed? 